\title{
First report of Maconellicoccus hirsutus (Green, 1908) (Hemiptera: Coccoidea: Pseudococcidae) and the associated parasitoid Anagyrus kamali Moursi, 1948 (Hymenoptera: Encyrtidae), in Brazil
}

\author{
Marsaro Júnior, AL. ${ }^{a}{ }^{*}$, Peronti, ALBG. ${ }^{b}$, Penteado-Dias, $A M .^{b}$, \\ Morais, EGF. ${ }^{c}$ and Pereira, PRVS. ${ }^{a}$ \\ a'Laboratório de Entomologia, Embrapa Trigo, BR 285, Km 294, CP 451, CEP 99001-970, Passo Fundo, RS, Brazil \\ bDepartamento de Ecologia e Biologia Evolutiva, Universidade Federal de São Carlos - UFSCar, \\ Rod. Washington Luiz, Km 235, CP 676, CEP 13565-905, São Carlos, SP, Brazil \\ 'Laboratório de Entomologia, Embrapa Roraima, BR 174, Km 08, CEP 69301-970, Boa Vista, RR, Brazil \\ *e-mail: alberto.marsaro@embrapa.br \\ Received April 2, 2012 - Accepted June 6, 2012 - Distributed May 31, 2013 \\ (With 7figures)
}

\begin{abstract}
The pink hibiscus mealybug (PHM), Maconellicoccus hirsutus (Green) (Hemiptera: Pseudococcidae) and the associated hymenopterous parasitoid, Anagyrus kamali Moursi, 1948 (Hymenoptera: Encyrtidae), are reported for the first time in Brazil. Specimens of the PHM were collected on nine hosts plants, Annona muricata L. (Anonnaceae), Glycine max (L.) Merr. (Fabaceae), Centrolobium paraensis Tul. (Fabaceae), Inga edulis Mart. (Fabaceae), Hibiscus rosasinensis L. (Malvaceae), Psidium guajava L. (Myrtaceae), Averrhoa carambola L. (Oxalidaceae), Citrus sinensis (L.) Osbeck (Rutaceae) and Solanum lycopersicum L. (Solanaceae), in four municipalities in the north-northeast of the state of Roraima. The plants $C$. paraensis, I. edulis and $C$. sinensis are recorded for the first time as a hosts for PHM. Characteristic injuries observed on the host plants infested by PHM and suggestions for its management are presented.
\end{abstract}

Keywords: pink hibiscus mealybug, quarantine pest, invasive species, geographical distribution, hosts plants.

Primeiro registro de Maconellicoccus hirsutus (Green, 1908) (Hemiptera: Coccoidea: Pseudococcidae) e do parasitoide associado, Anagyrus kamali Moursi, 1948 (Hymenoptera: Encyrtidae), no Brasil

\begin{abstract}
Resumo
A cochonilha rosada do hibisco (PHM), Maconellicoccus hirsutus (Green) (Hemiptera: Pseudococcidae) e o himenóptero parasitoide associado, Anagyrus kamali Moursi (Hymenoptera: Encyrtidae), são registrados pela primeira vez no Brasil. Exemplares dessa cochonilha foram coletados em nove plantas hospedeiras - Annona muricata L. (Anonnaceae); Glycine $\max ($ L.) Merr. (Fabaceae); Centrolobium paraensis Tul. (Fabaceae); Inga edulis Mart. (Fabaceae); Hibiscus rosasinensis L. (Malvaceae); Psidium guajava L. (Myrtaceae); Averrhoa carambola L. (Oxalidaceae); Citrus sinensis (L.) Osbeck (Rutaceae); Solanum lycopersicum L. (Solanaceae) -, em quatro municípios do norte-nordeste do Estado de Roraima. As plantas C. paraensis, I. edulis e C. sinensis são registradas pela primeira vez como hospedeiras para PHM. Injúrias características apresentadas pelas plantas hospedeiras infestadas pela cochonilha rosada e sugestões para o seu manejo são apresentados.
\end{abstract}

Palavras-chave: cochonilha rosada do hibisco, pragas quarentenárias, espécies invasivas, distribuição geográfica, plantas hospedeiras.

\section{Introduction}

The Pink Hibiscus Mealybug (PHM), Maconellicoccus hirsutus (Green, 1908) (Hemiptera: Pseudococcidae) is a polyphagous species of Pseudococcidae that feeds on a wide range of ornamental and agricultural host plant species distributed in 218 genera of 76 botanic families (Ben-Dov et al., 2011).

Macroscopically the body of the adult female of $M$. hirsutus is elongate oval, red-brown to orange-pink in

colour, usually 2.5-4.0 mm long, and is covered by white mealy wax. The mealy test has no bare areas on the dorsum and no conspicuous lateral wax filaments, characteristics that separates PHM from most other common Pseudococcidae (EPPO, 2005; Miller et al., 2011).

During oviposition, the female secretes a white wax ovisac of irregular shape resembling cotton, on which eggs are laid. Each female may deposit less than 100 to 
more than 600 eggs over a period of about one week, depending on the host plant species or food substrates (Ghose, 1972; Chong et al., 2008). The eggs are initially orange in colour, turning pink on maturity. Adult males are orange in colour, smaller than the females, with a pair of wings and two waxy caudal filaments; do not feed, living only a few days to mate (Stibick, 1997).

The PHM's toxic saliva and direct feeding cause various injuries in the host plants (Francis-Ellis, 1995). The injuries that characterise the presence of this particular mealybug on the host plants are distorted leaves and shoots, described as 'bunchy-top' deformation by Kairo et al. (2000); exhibited by hibiscus and by other host plants as citrus and cotton, but seems to be no rule to all host plants (Meyerdirk et al., 2002). Other injuries of the infested hosts include branch dieback, branch stunting and distortion, deformation or wilt and fall of flowers resulting in abnormal or non-development of fruits that may drop prematurely, thereby reducing the production and commercial value (Francis-Ellis, 1995; Meyerdirk et al., 2002).

The dispersion of this insect can occurs locally by crawlers, $0.3 \mathrm{~mm}$ long, and ovisacs, readily transported by wind or animals. The adult females and immatures have been known to travel short distances to get other host plants in adjoining fields. However the spreading over long distances is done mainly through transport by the host plants and, less frequently, via transport of fruits and flowers (Chang and Miller, 1996; EPPO, 2005).

Maconellicoccus hirsutus is probably native to Southern Asia and was described from samples collected in India, in 1908, on an undetermined shrub. This scale insect first spread into the Old World and later to the New World, mainly to tropical and subtropical parts (Williams, 1986, 1996). Currently this pest is known in Asia, West Indies, Northern Africa, Australia, the Pacific Islands, Southern USA, Central America and northern South America (BenDov et al., 2011).

In the Neotropical region, the PHM was reported in Grenada, Trinidad and St. Kitts in the early 1990's and quickly spread to at least 16 other islands of the Caribbean (Chang and Miller, 1996). In 1997, the PHM was reported in French Guiana, South America (Matile-Ferrero et al., 2000), and later recorded for other neighbouring countries as Republic of Guyana (USDA, 1997), Venezuela (Cermeli et al., 2002) and Colombia (Kondo et al., 2008). In 1999, it was also recorded in Belize and Mexico (Miller, 1999).

Tambasco et al. (2000) had already warned about the risk of entry of the PHM in Brazil due to the introduction in neighbouring countries. The present paper aims to report $M$. hirsutus for the first time to Brazil, as well as its parasitoids, dispersion and others host plants in Roraima State.

\section{Material and Methods}

Samples suspected to contain specimens of the PHM were originally collected, on leaves, buds and flowers of the H. rosa-sinensis, by the first author (A.L.M.J.), in the municipalities of Boa Vista ( $02^{\circ} 48^{\prime} 58.8^{\prime \prime} \mathrm{N}$ and $60^{\circ} 40^{\prime}$ 41.9" W), Bonfim ( $03^{\circ} 21^{\prime} 22.2^{\prime \prime} \mathrm{N}$ and $59^{\circ} 49^{\prime} 53.6^{\prime \prime}$ $\mathrm{W})$ and Pacaraima (04 $28^{\circ} 39.9^{\prime \prime} \mathrm{N}$ and $61^{\circ} 08^{\prime} 44.8^{\prime \prime}$ W), all in the state of Roraima, Brazil, in October 2010. Almost a year later, other samples suspected to be the PHM were collected on new hosts: one in the municipality of Normandia $\left(03^{\circ} 52^{\prime} 36.7^{\prime \prime} \mathrm{N}\right.$ and 59 38'00.8' $\mathrm{W}$ ), infesting fruits, buds and leaves of Annona muricata L. (Anonnaceae), collected by agricultural technicians of the Brazilian Institution, Ministério da Agricultura, Pecuária e Abastecimento (MAPA), in August 2011; and seven samples were collected by the fourth author (E.G.F.M.), of which four in the municipality of Boa Vista: on seedlings of Centrolobium paraensis Tul., Fabaceae, in September 2011; on buds of seedlings of the Solanum lycopersicum L., Solanaceae, in January 2012; on leaves and pods of the Glycine $\max$ (L.) Merr., Fabaceae, in February 2012 - $02^{\circ}$ $45^{\prime} 25.0^{\prime \prime} \mathrm{N}$ and $60^{\circ} 43^{\prime} 47.7^{\prime \prime} \mathrm{W}$ and on leaves and fruits of the Inga edulis Mart., Fabaceae, in April 2012 - $02^{\circ}$ 49' 55.6" $\mathrm{N}$ and $60^{\circ} 42^{\prime}$ 50.4" $\mathrm{W}$; and three samples in the municipality of Normandia: on leaves of the Psidium guajava L., Myrtaceae; on leaves and fruits of the Averrhoa carambola L., Oxalidaceae; on leaves of the orange, Citrus sinensis (L.) Osbeck (Rutaceae), in April 2012 - $03^{\circ}$ $53^{\prime} 00.5^{\prime \prime} \mathrm{N}$ and $59^{\circ} 38^{\prime} 25.1^{\prime \prime} \mathrm{W}$.

In order to investigate the possible spread of the PHM in the state of Roraima, agricultural technicians of MAPA inspected potential host plants, as $H$. rosa-sinensis and Malvaviscus arboreus Cav. (Malvaceae), in 91 localities of the municipalities located toward the south of the state, Cantá, Caracaraí, Caroebe, Iracema, Mucajaí, São João da Baliza, São Luiz do Anauá and Rorainópolis, between November and December 2011.

Part of the samples were stored in vials filled with $75 \%$ ethanol and the other part were placed in glass tubes, closed with cotton until the emergency of the parasitoids, and posteriorly stored in $100 \%$ ethanol. The mealybugs and the hymenopterous were identified respectively by the authors (A.L.B.G.P. and A.M.P.D.).

The mealybugs were mounted on microscopic slides following the methodology described by Gullan (1984) and identified according morphological characteristics of the adult female as described by (Miller 1999; Miller et al., 2011); the hymenopterous parasitoids were identified using Noyes and Hayat (1994). The specimens were deposited at the Universidade Federal de São Carlos, São Carlos, São Paulo, BR, and in the scale insect collection of the USDA-APHIS, Beltsville, USA.

A mealybug colony of PHM was reared and kept in the laboratory, at Embrapa in Roraima, to verify the possible occurrence of males.

\section{Results}

Pseudococcids collected in the municipalities of Bonfim and Pacaraima, on H. rosa-sinensis; in Boa Vista, on H. rosa-sinensis, C. paraensis, G. max, S. lycopersicum and I. edulis; and in the municipality of Normandia, on 
A. muricata, A. carambola, P. guajava and C. sinensis, were confirmed as PHM (Figure 1). The plants $C$. paraensis, I. edulis and $C$. sinensis are recorded for the first time as a hosts for PHM. This pest was not found in samples collected in the municipalities located in the south of the state of Roraima.

The injuries presented on the infested plants by $M$. hirsutus (Figure 2) were similar to those already described as 'bunchy-top' deformation (Figure 3) by Kairo et al. (2000). The eggs wrapped by the wax ovisac and all instars (Figures 4, 5) of $M$. hirsutus were found on deformed terminals of the host plant. Adult males were observed just next to the colonies of females of the PHM on $H$. rosa-sinensis collected in the field and from colonies reared in laboratory.
The parasitoid associated with the PHM was identified as Anagyrus kamali Moursi, 1948 (Hymenoptera: Encyrtidae) (Figures 6,7) and it emerged from specimens collected on H. rosa-sinensis and G. max in Boa Vista.

\section{Discussion}

In many countries, the PHM is not a problem, because it is chiefly restricted to Hibiscus, possibly due to efficient control by natural enemies (Meyerdirk et al., 2002). However, some regions have shown significant losses due to this pest, mainly in southern Asia and Egypt, where the PHM has a long history as a serious pest of agricultural, horticultural, and fibre crops, and more recently has become a pest in the Caribbean (Williams, 1986; Kairo et al.,

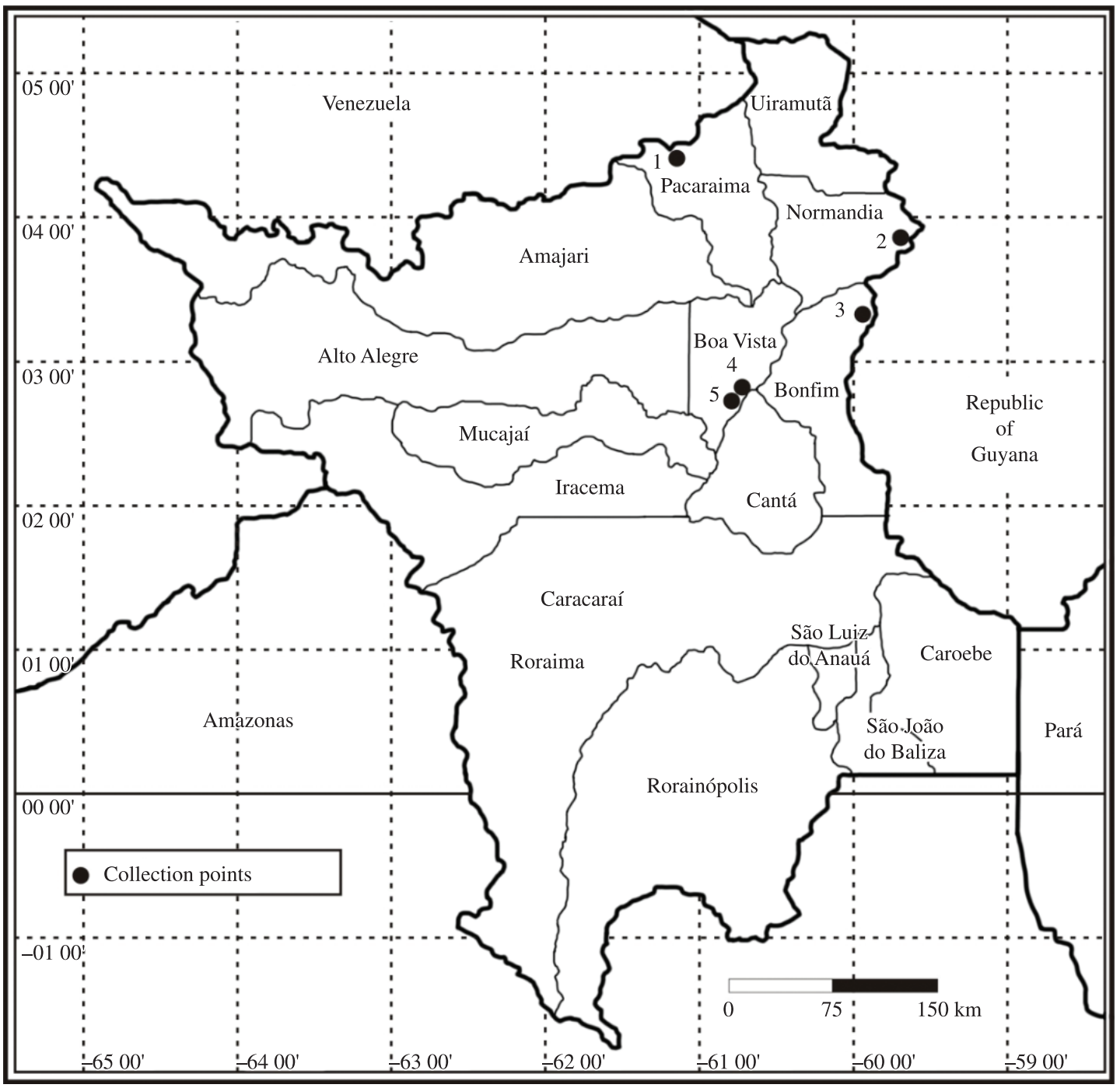

Figure 1. Map of the State of Roraima indicating the points in each municipality* and host plants where Maconellicoccus hirsutus (Green, 1908) was collected.

*1Pacaraima, Hibiscus rosa-sinensis; ${ }^{2}$ Normandia, Annona muricata, Psidium guajava, Averrhoa carambola, Citrus sinensis; ${ }^{3}$ Bonfim, Hibiscus rosa-sinensis; ${ }^{4}$ Boa Vista, Hibiscus rosa-sinensis, Inga edulis; ${ }^{5}$ Boa Vista, Centrolobium paraensis, Solanum lycopersicum and Glycine max. 


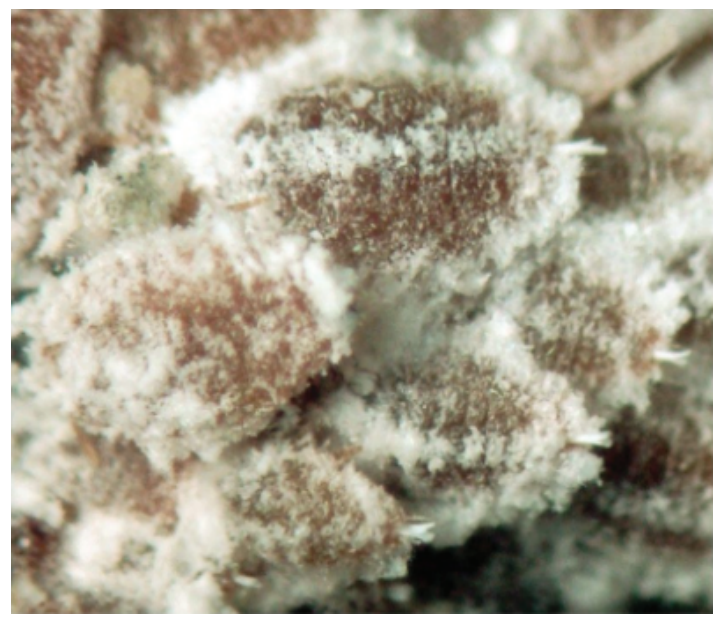

Figure 2. Adult females of M. hirsutus. Photo: Marsaro Júnior, A.L.

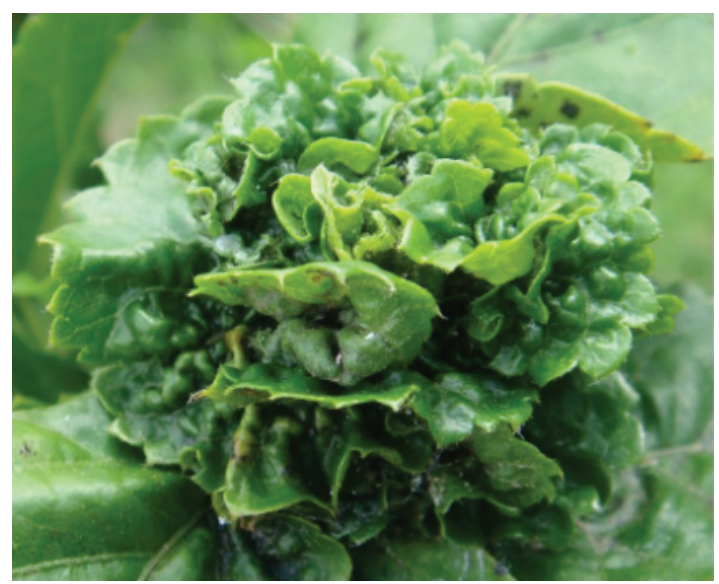

Figure 3. Typical injury presented by host plants infested by $M$. hirsutus, 'bunchy-top' deformation. Photo: Marsaro Júnior, A.L.

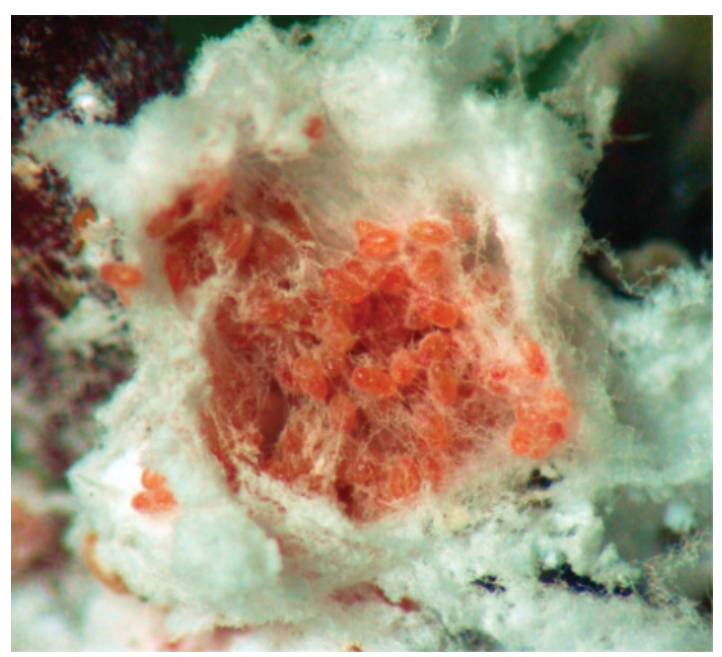

Figure 4. Figure 4. Ovissaco with eggs of M. hirsutus. Photo: Marsaro Júnior, A.L.

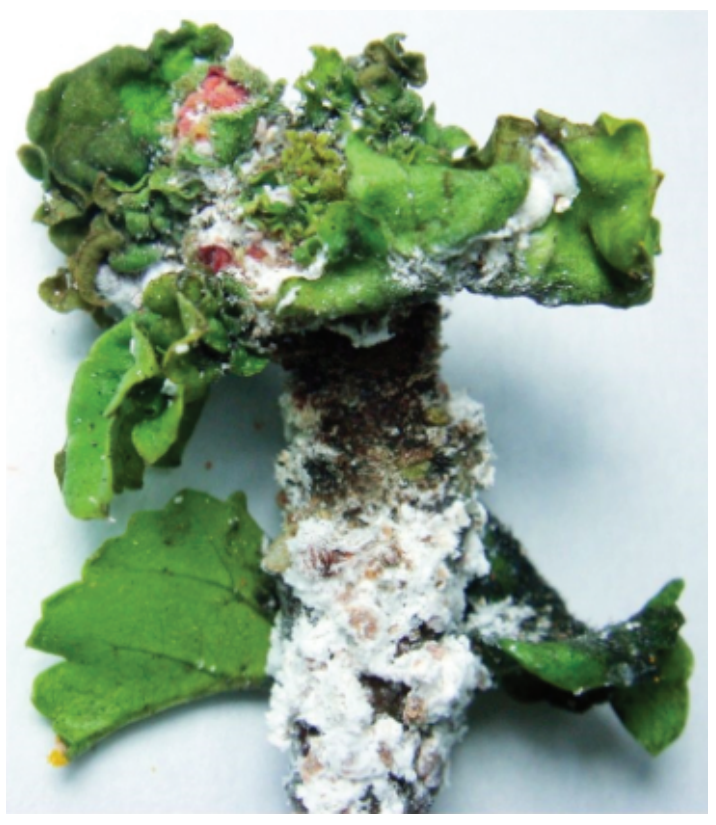

Figure 5. Colony of $M$.hirsutus on leaves, shoots and floral buttons of the H. rosa-sinensis. Photo: Marsaro Júnior, A.L.

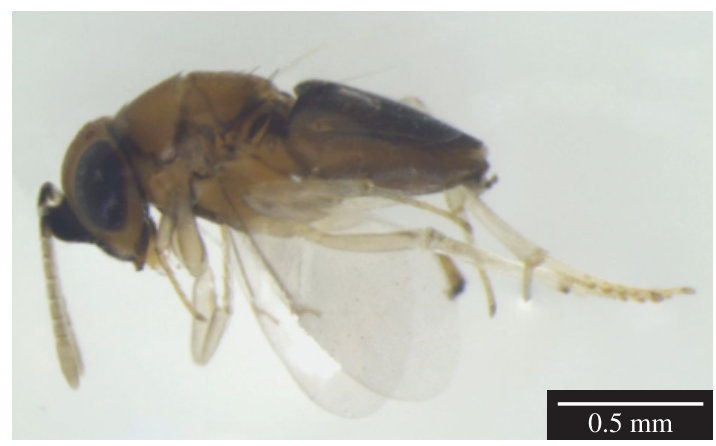

Figure 6. Adult female of A. kamali, hymenopteran parasitoid associated with $M$. hirsutus. Photo: PenteadoDias, A.M.

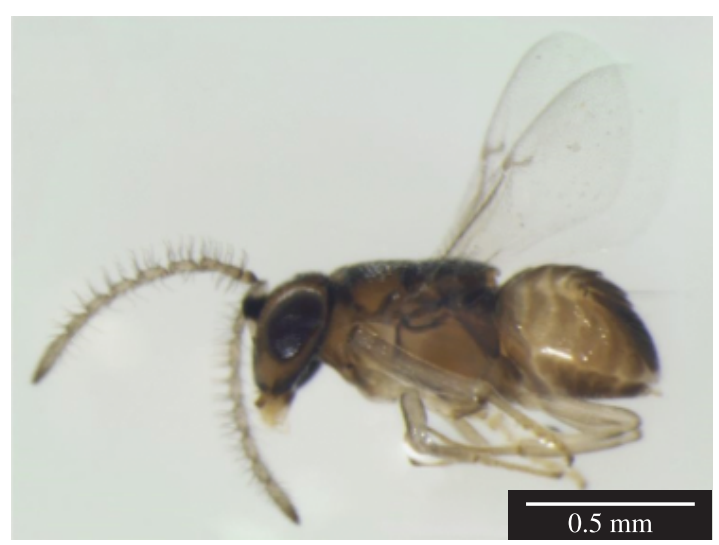

Figure 7. Adult male of A. kamali, hymenopteran parasitoid associated with M. hirsutus. Photo: Penteado-Dias, A.M. 
2000; Chong, 2009). In Grenada, Central America, the PHM caused estimated losses ranging from 3.5 to 10 million dollars in 1996/1997 season (Meyerdirk et al., 2002). If not controlled, the PHM could potentially cause estimated losses of $\$ 750$ millions/yr and $\$ 5$ billions over $10 \mathrm{yr}$ to agriculture in the United States (Moffitt, 1999 apud Chong, 2009).

In the state of Roraima, one year after the detection of the PHM, it was found only in four municipalities located in the north-northwest of the state (Figure 1), mainly in urban areas, but it has not been found yet in commercial plantations in rural areas, however, the number of host plants has increased, showing a good adaptation of the species in the region.

Methods to control the PHM include the use of insecticides, cultural practices, and biological control (Chang and Miller, 1996). The PHM is difficult to control by traditional chemical management because the insect lives in protected conditions: the body is covered by a mealy waxy layer and their eggs are protected within a filamentous secretion (the ovisac) (Kairo et al., 2000); and by the cryptic behaviour of mealybugs that are found aggregated in protected parts of their host plant which difficults a thorough coverage of pesticide applications (Chong, 2009). Biological control using parasitoids and predators, seems to be the most feasible control alternative. There are several control programmes under development in regions where the PHM has settled, with promising results (Kairo et al., 2000; Meyerdirk et al., 2002). The predators are mainly species of Coccinellidae (Coleoptera), Cecidomyiidae and Drosophilidae (Diptera), and the parasitoids include species of Aphelinidae, Encyrtidae, Pteromalidae and Signiphoridae (Hymenoptera).

The parasitoid, A. kamali, associated with the PHM in Roraima, was probably introduced together with the pseudococcid. This parasitoid was introduced from China, together with other parasitoids and predators into the Caribbean Islands in a Biological Control programme, and proved to be one of the most efficient control methods of the PHM (Chong, 2009). In Roraima, plants of $H$. rosa-sinensis attacked by PHM has been regularly monitored and has been verified high rates of parasitism this mealybug by $A$. kamali, indicating that this parasitoid may be contributing to the regulation of the population of this pest in the state.

Immediately after the confirmation of the identification of the PHM in Roraima State, the MAPA was communicated, according to IN 52 of the MAPA (Brasil, 2007). Preventive measures to reduce the spread of this pest in Brazil are already being adopted, through the IN 30 of the MAPA (Brasil, 2011), which prohibits the transport of seedlings and other propagating material, except seeds and material in vitro, of any plant species from the state of Roraima to other Brazilian states. The fruits of host plants, from Roraima, may only be transported to other states after inspection by qualified technicians of Agência de Defesa Agropecuária do Estado de Roraima (ADERR) and emission of the Vegetable Transit Permit (PTV), document permitting the transit of vegetables, if the PHM is absent on the fruits.
For the monitoring of the geographic distribution of $M$. hirsutus in Brazil we suggest following the example of other countries, the use of the delta style traps baited with sex pheromones, as suggested by Gonzalez-Gaona et al. (2010).

Acknowledgements - We are grateful to Dr. Douglass R. Miller of the "Systematic Entomology Laboratory (SEL), U.S. Department of Agriculture, Agricultural Research Service", Beltsville, EUA, for confirming the initial identification of Maconellicoccus hirsutus (Green); to the researchers and technicians of the Entomology Laboratory - "Empresa Brasileira de Pesquisa Agropecuária (EMBRAPA)" of the state of Roraima, for their support in field collection and use of the physical structure and equipment; to Dr. Takumasa Kondo (CORPOICA, Palmira, Colombia) for reviewing the manuscript; to Mr. Rudolf Zeidler, MAPA, for the information given to the authors.

\section{References}

BEN-DOV, Y., MILLER, DR. and GIBSON, GAH., 2011. ScaleNet. Available from: <http://www.sel.barc.usda.gov/ scalenet/ scalenet.htm>. Access in: 10 Nov 2011.

Brasil. Ministério da Agricultura, Pecuária e Abastecimento MAPA, 2007. Instrução normativa $\mathrm{n}^{\circ} 52$, de 20 de novembro de 2007. : Estabelece a lista de pragas quarentenárias ausentes (A1) e de pragas quarentenárias presentes (A2) para o Brasil e aprova os procedimentos para as suas atualizações. Diário Oficial da República Federativa do Brasil, Brasília, 21 nov. Seção 1. Available from: <http://sistemasweb.agricultura.gov.br/sislegis/ action/detalhaAto.do?method=detalharAtosArvore\&tipo=INM \&numeroAto $=00000052 \&$ seqAto $=000 \&$ valor $A$ no $=2007 \&$ orga $\mathrm{o}=$ MAPA\&codTipo $=\&$ desItem $=\&$ desItemFim $=\#>$. Access in: 20 May 2013.

-, 2011. Instrução normativa $\mathrm{n}^{\circ}$ 30, de 24 de agosto de 2011. Restringe o trânsito de mudas e demais materiais de propagação provenientes do estado de Roraima para qualquer Unidade da Federação, em virtude da Cochonilha Rosada do Hibisco (Maconellicoccus hirsutus). Diário Oficial da República Federativa do Brasil, Brasília, 25 ago. Seção 1. Available from: <http:// sistemasweb.agricultura.gov.br/sislegis/action/detalhaAto.do? method $=$ detalharAtosArvore \& tipo $=I N M \&$ numeroAto $=00000$ $030 \&$ seqAto $=000 \&$ valor $A n o=2011 \&$ orgao $=$ SDA $/$ MAPA\&co dTipo=\&desItem $=\&$ desItemFim=\#>. Access in: 20 May 2013.

CERMELI, M., MORALES, P., GODOY, F., ROMERO, R. and CÁRDENAS, O., 2002. Presencia de la cochinilla rosada de la cayena Maconellicoccus hirsutus (Green) (Hemiptera: Pseudococcidae) en Venezuela. Entomotropica, vol. 17, p. 103-105.

CHANG, LWH and MILLER, CE., 1996. Pathway risk assessment: pink mealybug from the Caribbean. Planning and Risk Analysis Systems, Policy and Program Development. USDA-APHIS. 61 p.

CHONG, JH., 2009. First Report of the Pink Hibiscus Mealybug, Maconellicoccus hirsutus (Green) (Hemiptera: Pseudococcidae), in South Carolina. Journal of Agricultural and Urban Entomology, vol. 26, p. 87-94. http://dx.doi.org/10.3954/1523-5475-26.2.87

CHONG, JH., RODA, AL. and MANNION, CM., 2008. Life history of the mealybug, Maconellicoccus hirsutus (Hemiptera: Pseudococcidae), at constant temperatures. Environmental Entomology, vol. 37, p. 323-332. http://dx.doi.org/10.1603/0046225X(2008)37[323:LHOTMM]2.0.CO;2 
European and Mediterranean Plant Protection Organization - EPPO, 2005. Data sheets on quarantine pests Maconellicoccus hirsutus. Available from: <http://www.eppo. org/QUARANTINE/insects/Maconellicoccus_hirsutus/DS_ Maconellicoccus_hirsutus.pdf>. Access in: 10 Nov 2011.

FRANCIS-ELLIS, D., 1995. Paper on background and status of mealybug Maconellicoccus hirsutus in Grenada. Grenada: Ministry of Agriculture. 7 p.

GHOSE, SK., 1972. Biology of the mealybug Maconellicoccus hirsutus (Green) (Pseudococcidae: Hemiptera). Indian Agriculture, vol. 16, p. 323-332.

GULLAN, PJ., 1984. A revision of the gall-forming coccoid genus Apiomorpha Rübsaamen (Homoptera: Eriococcidae: Apiomorphinae). Australian Journal of Zoology, Supplementary Series, vol. 97, p. 1-203.

GONZALEZ-GAONA, E., SANCHEZ-MARTINEZ, G., ZHANG, A., LOZANO-GUTIERREZ, J. and CARMONA-SOSA, F., 2010. Validation of two Pheromonal Compounds for Monitoring Pink Hibiscus Mealybug in Mexico. Agrociencia, vol. 44, p. 65-73.

KAIRO, MTK., POLLARD, GV., PETERKIN, DD. and LOPEZ, VF., 2000. Biological control of the hibiscus mealybug, Maconellicoccus hirsutus Green (Hemiptera: Pseudococcidae) in the Caribbean. Integrated Pest Management Reviews, vol. 5, p. 241-254. http://dx.doi.org/10.1023/A:1012997619132

KONDO, T., RAMOS-PORTILLA, AA. and VERGARANAVARRO, EV., 2008. Updated list of mealybugs and putoids from Colombia (Hemiptera: Pseudococcidae and Putoidae). Boletín del Museo de Entomología de la Universidad del Valle, vol. 9, p. 29-53.

MATILE-FERRERO, D., ÉTIENNE, J. and TIEGO, G., 2000. Introduction de deux ravageurs d'importance pour la Guyane française: Maconellicoccus hirsutus et Paracoccus marginatus (Hem., Coccoidea, Pseudococcidae). Bulletin de la Société Entomologique de France, vol. 105, p. 485-486.

MEYERDIRK, DE., WARKENTIN, R., ATTAVIAN, B., GERSABECK, E., FRANCIS, A., ADAMS, J. and FRANCIS,
G., 2002. Biological control of pink hibiscus mealybug project manual. United States Dept. of Agric., Animal and Plant Health Inspection Service, Plant Protection and Quarantine. 194 p. Available from: <http://www.aphis.usda.gov/ppq/manuals/pdf_Wles/phm.pdf>.

MILLER, DR., 1999. Identification of the Pink Hibiscus Mealybug, Maconellicoccus hirsutus (Green) (Hemiptera: Sternorrhyncha: Pseudococcidae). Insecta Mundi, vol. 13, p. 189-203.

MILLER, DR., RUNG, A., VENABLE, GL. and GILL, RJ., 2011. Scale insects: identification tools for species of quarantine importance. Scale Families. ARS \& APHIS, USDA. Available from: <http://www.sel.barc.usda.gov/ScaleKeys/ScaleInsectsHome/ ScaleInsectsFamilies.html>. Access in: 10 Nov 2011.

NOYES, JS., HAYAT, M., 1994. Oriental mealybug parasitoids of the Anagyrini (Hymenoptera: Encyrtidae). Oxon: CAB International. $554 \mathrm{p}$.

STIBICK, JNL., 1997. Pink hibiscus mealybug, new pest response guidelines. United States Department of Agriculture. 104 p.

TAMBASCO, FJ., SÁ, LAN., NARDO, EBA., TAVARES, MT., 2000. Cochonilha rosada, Maconellicoccus hirsutus (Green): uma praga de importância quarentenária já se encontra na Guiana Inglesa. Floresta, vol. 30, p. 85-93.

United States Departament of Agriculture (USDA) - Animal and Plant Health and Inspection Service (APHIS), 1997. Look out for the pink hibiscus mealybug. United States Department of Agriculture. Program Aid no. 1606. 11 p.

WILLIAMS, DJ., 1986. The identity and distribution of the genus Maconellicoccus Ezzat (Hemiptera: Pseudococcidae) in Africa. Bulletin of Entomological Research, vol. 76, p. 351-357. http:// dx.doi.org/10.1017/S0007485300014814

-, 1996. A brief account of the hibiscus mealybug Maconellicoccus hirsutus (Hemiptera: Pseudococcidae), a pest of agriculture and horticulture, with descriptions of two related species from southern Asia. Bulletin of Entomological Research, vol. 86, p. 617-628. http://dx.doi.org/10.1017/S0007485300039420 